\title{
NOCARDIOSIS: AN OVERVIEW AND ADDITIONAL REPORT OF 28 CASES IN CATTLE AND DOGS
}

\author{
Márcio Garcia RIBEIRO(1), Tatiana SALERNO(2), Ana Luiza de MATTOS-GUARALDI(3), Thereza Cristina Ferreira CAMELLO(3), Hélio LANGONI(4), Amanda Keller
} SIQUEIRA(2), Antonio Carlos PAES(1), Marta Catarina FERNANDES(1) \& Gustavo Henrique Batista LARA(2)

\begin{abstract}
SUMMARY
Phenotypic characteristics, antimicrobial susceptibility profile, and clinical-epidemiological features of 28 Nocardia strains isolated from 19 cases of bovine mastitis, eight cutaneous-subcutaneous lesions and one case of pneumonia in dogs were evaluated. Microbiological, biochemical, cytological and scanning electron microscopy methods were used in diagnosis. Nocardia asteroides type IV, Nocardia otitidiscaviarum, Nocardia nova (type III) and Nocardia farcinica (type V) were isolated from bovine milk, bronchial lavage and/or cutaneous-subcutaneous abscesses in dogs. Nocardial bovine mastitis was diagnosed predominantly in clinical cases, in dairy herds with poor environmental hygienic conditions between milking and inappropriate intramammary therapy. Canine nocardiosis was observed commonly in animals co-infected with distemper virus. Sulphamethoxazole-trimethoprim (92.8\%), amikacin (92.8\%) and ceftiofur (92.8\%) were the most effective drugs in 28 isolates. Multiple drug resistance to three or more and five or more antimicrobials was observed in ten $(35.7 \%)$ and three $(10.7 \%)$ strains, respectively, predominantly with use of cloxaxillin, cefoperazone and ampicillin. The species (type) classification, clinical-epidemiological characteristics, diagnosis, multiple drug resistance and public health considerations in Nocardia strains isolated from cattle and dogs in Brazil are discussed, with special reference to report of bovine mastitis by $N$. otitidiscaviarum by first time in Brazil and the similarity between Nocardia species isolated from human and animal origin.
\end{abstract}

KEYWORDS: Nocardiosis; Nocardia asteroides; Nocardia otitidiscaviarum; Bovine; Dog; Milk; Mastitis; Brazil.

\section{INTRODUCTION}

Nocardia are microorganisms ubiquitous, soil saprophytes, found in organic material, water and plants. Pyogranulomatous suppurative processes with chronic evolution and refractory to the conventional antimicrobial therapy, characterize infections caused by actinomycetes, including Nocardia $\operatorname{spp}^{26,37}$.

Pathogenicity of Nocardia species is influenced by bacterial intracellular localization, induction of pyogranulomatous inflammatory response, host susceptibility, via of transmission and co-infection with immunosuppressive diseases. These facultative intracellular pathogens, are able to inhibit phagosome-lizosome fusion, and resist to acid, oxidative and other enzyme mechanisms into neutrophils and macrophages, due to presence of mycolic acids in bacterial cell wall, resulting in severe tissue inflammatory processes ${ }^{6,19}$.

The human and animal nocardiosis generally are refractory to conventional antimicrobial therapy. Trimethoprim-sulfonamides combinations, cephalosporins, amikacin, ampicillin, imipenem, minocycline and linezolid are drugs recommended for nocardial treatment that involves antimicrobial prolonged course combined with support therapy and surgical procedures. However, the prognosis is uncertain, especially in intramammary infections in domestic ruminants and disseminated infections in companion animals ${ }^{26,37}$.

Bovine mastitis is the most common clinical manifestation of nocardiosis among domestic ruminants. Nocardial mastitis is usually encountered in dairy herds with poor hygienic conditions between milking, caused by soil contamination in udder washing, teatdips or intramammary infusions, especially in dry period ${ }^{37}$. In earlier investigations done in Brazil, $24 N$. asteroides and $2 N$. brasiliensis strains were identified in cattle presenting mastitis ${ }^{20}$. Later, a total of 20,310 quarters from 5.216 cattle were submitted to microbiological culture for diagnosis of mastitis and, from these, Nocardia sp. represented $6.6 \%$ of the isolates ${ }^{22}$. Similar study evolving etiology of bovine mastitis evaluated 91 lactating and 47 dry cows, and revealed Nocardia spp. in $4.55 \%$ and $2.15 \%$ from lactating and dry cows, respectively ${ }^{23}$.

Cutaneous-subcutaneous abscess and pneumonia are usual clinical signs of nocardiosis in companion animals. Canine nocardiosis frequently occur by inhalation of organism from soil or secondary to skin inoculation through a puncture wounds ${ }^{27}$. 


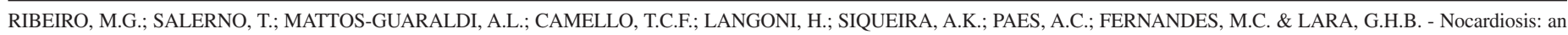
overview and additional report of 28 cases in cattle and dogs. Rev. Inst. Med. trop. S. Paulo, 50(3): 177-185, 2008.

Human nocardiosis is recognized as opportunistic disease, presenting commonly in cutaneous-subcutaneous, pulmonary and/or neurological signs. Severe clinical symptoms are described in specific groups of risk, including transplanted patients, alcoholics, chronic diseases (lupus, leukaemia, neoplasms and tuberculosis) and acquired immunodeficiency syndrome - aids ${ }^{1,15,19}$.

In recent years, according the biochemical characteristics, antimicrobial susceptibility and molecular methods ${ }^{17,40}$, the classification of genera was re-defined. The more important pathogenic species for disease in humans and animals were classified as: Nocardia asteroides (N. asteroides) complex, Nocardia brasiliensis ( $N$. brasiliensis), Nocardia pseudobrasiliensis, Nocardia transvalensis and Nocardia otitidiscaviarum ( $N$. otitidiscaviarum). N. asteroides complex have been recognized as type I, II, III, IV, V and VI. The type III is called as $N$. nova and type $\mathrm{V}$ as $N$. farcinica ${ }^{10,26,28,48}$. The present study aimed to characterize 28 nocardiform strains isolated from clinical samples obtained from cattle and dogs in Brazil, using microbiological, biochemical, cytological and/or scanning electron microscopy methods. The antimicrobial susceptibility profiles of microorganism, addition to some clinical-epidemiological and Public Health aspects were also subjects of interest.

\section{MATERIAL AND METHODS}

\section{Clinical and epidemiological features}

Dogs: In the period between the years 2000 and 2006, eight dogs with cutaneous-subcutaneous lesions and one dog presenting pneumonia caused by Nocardia were admitted in the Clinical Ambulatory of Infectious Diseases of Domestic Animals at Faculdade de Medicina Veterinária e Zootecnia-FMVZ-UNESP, Botucatu, SP, Brazil. All the animals were submitted to complete clinical exam. Tracheo-bronchial lavage was performed in animals with signs of pneumonia and the material submitted to cytological and microbiological examination. Biopsy fragments (fine needle aspiration) ${ }^{39}$ were aseptically obtained from cutaneous-subcutaneous lesions, and also submitted to cytological and microbiological procedures.

Diagnosis of debilitate or immunosuppressive infectious diseases in dogs, with special interest in canine distemper, was performed based on epidemiological data from animals, such as age, gender, vaccination status, access to street, contact with others animals and clinical signs. Distemper virus inclusions bodies were diagnosed in peripheral blood smear staining by Giemsa and Leishmann ${ }^{18}$. Additionally, the dogs were submitted to complete hematological exams. The treatment of dogs was attempted using predominantly sulphamethoxazoletrimethoprim (50 mg/kg, SC, once a day for 20 days), aggressive fluid therapy and support therapy procedures. Post-mortem examination included brain and lung impression smears stained by Giemsa for detection of distemper inclusion bodies presence ${ }^{18,26,33}$.

Cattle: A total of 19 Holstein cows from 17 different dairy farms management in manual or machine milking, raised in São Paulo State, Brazil, with a history of clinical or subclinical mastitis were diagnosed with nocardiosis in the Laboratory of Infectious Diseases of Domestic Animals and Research Nucleus on Mastitis-NUPEMAS, at FMVZUNESP, Botucatu, SP, Brazil, between 2000 and 2006. Milk from all quarters of 19 animals was examined by the strip cup test and California Mastitis Test-CMT ${ }^{46}$ for the diagnosis of clinical and subclinical mastitis, respectively. Complete clinical exam of udder and mammary glands was also performed ${ }^{37}$. Before milking procedure, teats from 19 animals were washed and disinfected. Milk from all quarters from animals (either presenting or not mastitis) were aseptically collected prior to milking, kept at a temperature of $0-4{ }^{\circ} \mathrm{C}$, and submitted to microbiological exams.

\section{Cytological techniques}

Fine needle aspiration using Valeri TM, cytoaspirator (MPJ Equipamentos Médicos, Ribeirão Preto, SP, Brazil), hypodermic needles $(30 \times 7 \mathrm{~mm})$ and individual disposable syringes $(10 \mathrm{~mL})$ was performed in eight cutaneous-subcutaneous lesions (abscesses) in $\operatorname{dogs}^{39}$. Aspired material was submitted to cytological examination by means of Gram and Giemsa staining as described elsewhere ${ }^{36}$.

\section{Microbiological procedures}

Material obtained from bronchial lavage and cutaneoussubcutaneous lesions of the dogs, and milk from cattle were submitted to microbiological culture aerobically at a temperature of $37{ }^{\circ} \mathrm{C}$ using the following media: $5 \%$ defibrinated sheep blood agar and MacConkey agar during four days and, Sabouraud-dextrose agar during 15 days. Nocardia-like colonies were submitted to Gram and acid-fast stain (modified Ziehl-Neelsen - MZN) ${ }^{29,36}$. Conventional biochemical characterization of Nocardia spp. was based on use of different substrates (casein, xanthine, hipoxanthine and tyrosine). Additionally, microorganisms were also submitted to the commercial API 20C AUX strips TM, (BioMeriex, Hazelwood, MO), based on the evaluation of different carbohydrates assimilation (glucose, glycerol, galactose, glucosamine, inositol, adonitol, trehalose) and use of other substrates (arylsulfatase, acetamide, gelatin liquefaction) $)^{28,44}$.

\section{Antimicrobial susceptibility test}

All the Nocardia strains were submitted to antimicrobial susceptibility test by means of diffusion disk method ${ }^{5,16}$ using amikacin (30 $\mu \mathrm{g})$, ampicillin $(10 \mu \mathrm{g})$, amoxicillin-clavulanic acid $(20 / 10 \mu \mathrm{g})$, ceftiofur $(30 \mu \mathrm{g})$, cefoperazone $(75 \mu \mathrm{g})$, ceftriaxone $(30 \mu \mathrm{g})$, cloxacillin $(5 \mu \mathrm{g})$, gentamicin $(10 \mu \mathrm{g})$, sulphamethoxazole-trimethoprim $(25 \mu \mathrm{g})$. Multiple drug resistance was considered when the isolates present resistance to three or more antimicrobials simultaneously.

\section{Electron microscopy technique}

Three strains identified as Nocardia asteroides type IV isolated from bovine mastitis were submitted to scanning electron microscopy technique ${ }^{24}$. Briefly, three or four pure colonies of microorganisms obtained in sheep blood agar $(5 \%)$ were re-suspended in $5 \mathrm{~mL}$ of $\mathrm{NaCl}$ solution $(0.85 \%)$ in glass tubes. Bacterial cells were fixed in $2.5 \%$ of glutaraldeyde in $0.1 \mathrm{M}$ phosphate buffer $(\mathrm{pH} 7.3)$, post-fixed in $1.0 \%$ osmium tetroxide solution in same buffer solution. Finally, were dehydrated in graded ethanol solution, critical point dried with liquid $\mathrm{CO}_{2}$, and coated with gold layer $(10 \mathrm{~nm})$. The material was photographed and analyzed using a Philips SEM 515 Scanning Electron Microscope. 


\section{RESULTS}

Table 1 summarizes the most relevant clinical-epidemiological features of Nocardia strains isolated from cattle and dogs highlighted in the present study.

In the great majority of dogs, vaccination status was incomplete or unknown and the animals had access to street. There was no significant difference in occurrence of canine nocardiosis when evaluated gender and age (Table 1). The cutaneous-subcutaneous lesions (abscesses) in eight dogs were characterized by firm to fluctuant masses, with multiple draining sinuses, and exudation of serosanguinous to purulent secretion containing whitish granules ("sulfur granules"), predominantly in cervical and inguinal regions of skin (Fig. 1). In some animals, regional lymph nodes were committed. Dyspnea, fever, apathy, mucopurulent nasal discharge, weight loss and anorexia were the most-common clinical signs in dog with pneumonia. Five (55.5\%) from nine dogs with nocardiosis were found co-infected with distemper virus, and from these, four showed worsened corporal conditions and died, including the animal with pneumonia (Table1).

Exams of the udder revealed that $16(84.2 \%)$ and three $(15.8 \%)$ cows present clinical and subclinical mastitis, respectively. Affected glands in clinical cases showed edema, fibrosis and masses to palpation, with draining sinuses. Viscous, seropurulent, yellow to grayish secretion containing white particles ("sulfur granules") were observed after milking of affected quarters. Subclinical mastitis displayed 2 to $3+$ in CMT. In only three dairy farms were found two animals with nocardial mastitis. In two herds, were observed one animal with clinical and other with subclinical mastitis (Table 1, animals 04, 05 and 17, 18) while in the third herd two animals presented clinical mastitis (Table 1 , animals 10,11$)$. Intramammary therapy was attempted in only five from 19 cattle with clinical mastitis, without efficacy.

Whitish to orange, circular, dry, convex colonies, with powdery surface firmly adherent to agar surface, were observed in sheep blood agar after 72-96 hours of microbiological culture, obtained from bovine milk, bronchial lavage and aspired secretion from cutaneoussubcutaneous lesions in dogs. Likewise, dry, whitish to orange, irregular colonies were isolated in Sabouraud dextrose agar, after 96 hours of incubation. Gram-positive, partially acid-fast (MZN-positive), filamentous to cocobacillary organisms were identified in both media. Growth of microorganisms was not observed in MacConkey agar. Aspired material from cutaneous-subcutaneous lesions from dogs revealed long filamentous organisms with tendency to fragmentation in cocobacillary forms, with poor dense mats of microorganisms, suggestive of Nocardia spp. (Fig. 2). The scanning electron microscopy revealed detail of filamentous to cocobacillary organisms of Nocardia asteroides type IV isolated from bovine mastitis (Fig. 3).

Sulphamethoxazole-trimethoprim (92.8\%), amikacin $(92.8 \%)$, ceftiofur $(92.8 \%)$ and gentamicin $(85.8 \%)$ were the most effective drugs for 28 Nocardia clinical isolates. The strains showed high levels of resistance to cloxacillin (96.4\%), cefoperazone (92.8\%) and ampicillin (28.4\%) (Table 2). Multiple drug resistance to three or more and five or more antimicrobials was observed in ten $(35.7 \%)$ and three $(10.7 \%)$ strains, respectively, predominantly associated to the use of cloxaxillin, cefoperazone and ampicillin.

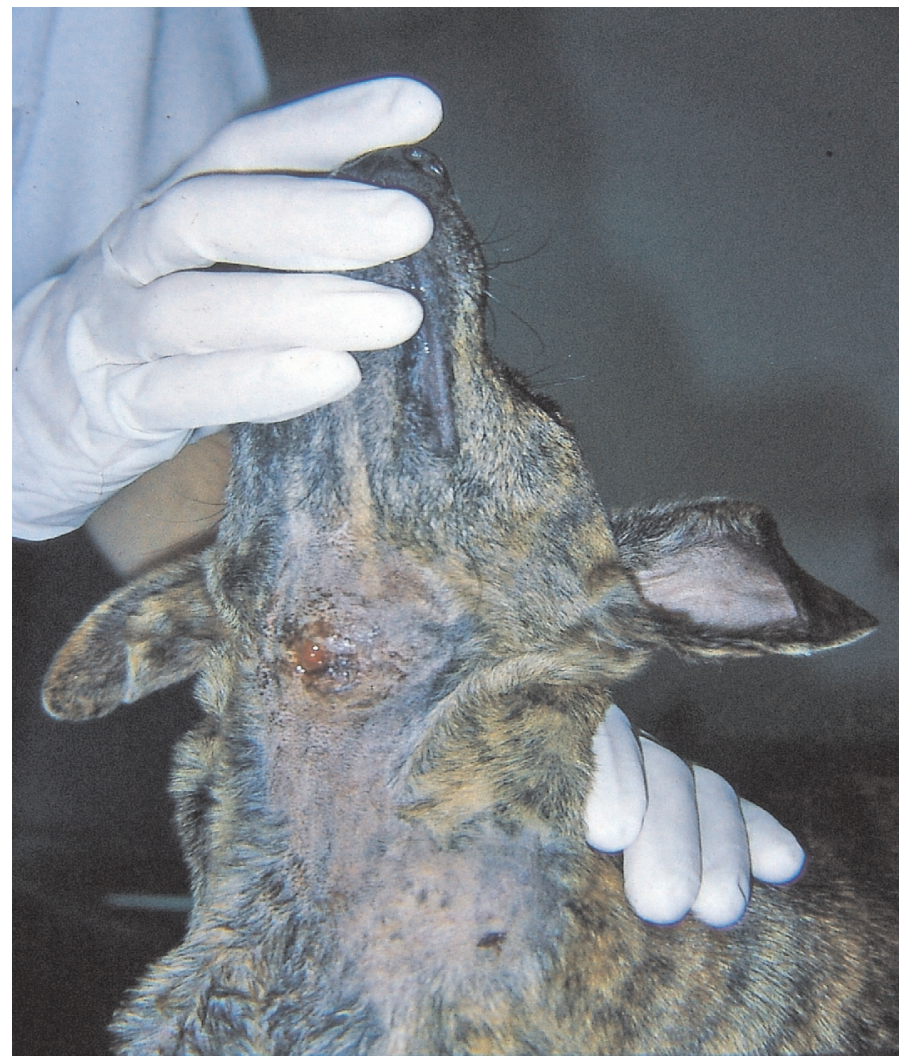

Fig. 1 - Fluctuant mass containing purulent secretion in a dog with cutaneous-subcutaneous lesion, caused by Nocardia otitidiscaviarum. São Paulo State, Brazil, 2005.

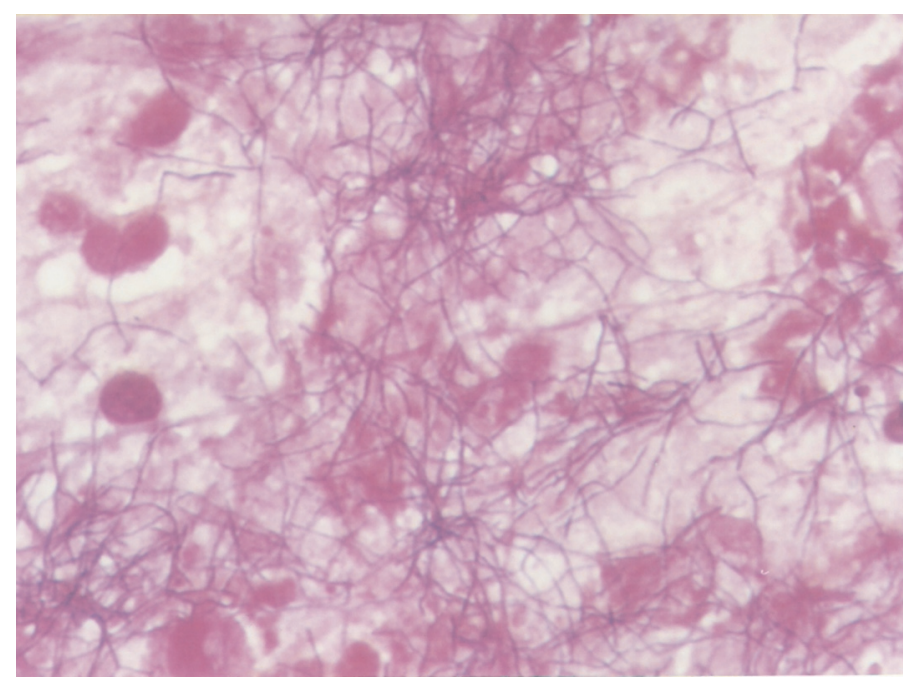

Fig. 2 - Gram-positive, filamentous organisms with tendency to fragmentation in coccobacillary forms of Nocardia otitidiscaviarum obtained by biopsy of cutaneoussubcutaneous lesion in a dog. São Paulo State, Brazil, 2005 (Gram, Magnification 1000x).

\section{DISCUSSION}

Currently, nocardiosis has been considered an emerging disease among humans and domestic animals worldwide. Classically, $N$. 


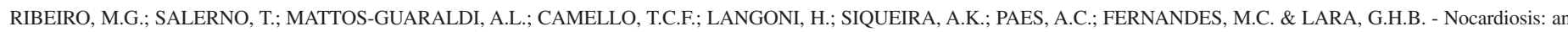
overview and additional report of 28 cases in cattle and dogs. Rev. Inst. Med. trop. S. Paulo, 50(3): 177-185, 2008.

Table 1

Clinico-epidemiological aspects and species (type) characterization of 28 Nocardia strains identified in cattle and dogs. Brazil, 2000 - 2006

\begin{tabular}{|c|c|c|c|c|c|c|c|}
\hline Number & $\begin{array}{c}\text { Age } \\
\text { (months) }\end{array}$ & Year & Animal/Gender & $\begin{array}{c}\text { Clinical } \\
\text { manifestation }\end{array}$ & $\begin{array}{l}\text { Combined } \\
\text { infection }\end{array}$ & Outcome & Type classification \\
\hline 01 & $>48$ & 2000 & Bovine/Female & Clinical mastitis & No & Unknown & Nocardia otitidiscaviarum \\
\hline 02 & $>48$ & 2001 & Bovine/Female & Clinical mastitis & No & Unknown & $\begin{array}{l}\text { Nocardia asteroides type III } \\
\text { (N. nova) }\end{array}$ \\
\hline 03 & $>48$ & 2001 & Bovine/Female & Clinical mastitis & No & Unknown & $\begin{array}{l}\text { Nocardia asteroides type III } \\
(N . \text { nova) }\end{array}$ \\
\hline 04 & $>48$ & 2001 & Bovine/Female & Subclinical mastitis & No & Unknown & Nocardia asteroides type IV \\
\hline 05 & $>48$ & 2001 & Bovine/Female & Clinical mastitis & No & Unknown & Nocardia asteroides type IV \\
\hline 06 & $>48$ & 2003 & Bovine/Female & Clinical mastitis & No & Unknown & $\begin{array}{l}\text { Nocardia asteroides type V } \\
\text { (N. farcinica) }\end{array}$ \\
\hline 07 & $>48$ & 2003 & Bovine/Female & Clinical mastitis & No & Unknown & $\begin{array}{l}\text { Nocardia asteroides type } \mathrm{V} \\
\text { (N. farcinica) }\end{array}$ \\
\hline 08 & $>48$ & 2003 & Bovine/Female & Subclinical mastitis & No & Unknown & $\begin{array}{l}\text { Nocardia asteroides type III } \\
(\text { N. nova })\end{array}$ \\
\hline 09 & $>48$ & 2003 & Bovine/Female & Clinical mastitis & No & Unknown & $\begin{array}{l}\text { Nocardia asteroides type III } \\
\text { (N. nova) }\end{array}$ \\
\hline 10 & $>48$ & 2003 & Bovine/Female & Clinical mastitis & No & Unknown & $\begin{array}{l}\text { Nocardia asteroides type III } \\
(N . \text { nova })\end{array}$ \\
\hline 11 & $>48$ & 2003 & Bovine/Female & Clinical mastitis & No & Unknown & $\begin{array}{l}\text { Nocardia asteroides type III } \\
(N . \text { nova) }\end{array}$ \\
\hline 12 & $>48$ & 2003 & Bovine/Female & Clinical mastitis & No & Unknown & $\begin{array}{l}\text { Nocardia asteroides type III } \\
\text { (N. nova) }\end{array}$ \\
\hline 13 & $>48$ & 2003 & Bovine/Female & Clinical mastitis & No & Unknown & Nocardia otitidiscaviarum \\
\hline 14 & $>48$ & 2004 & Bovine/Female & Clinical mastitis & No & Unknown & Nocardia otitidiscaviarum \\
\hline 15 & $>48$ & 2005 & Bovine/Female & Clinical mastitis & No & Unknown & Nocardia asteroides type IV \\
\hline 16 & $>48$ & 2006 & Bovine/Female & Clinical mastitis & No & Unknown & Nocardia asteroides type IV \\
\hline 17 & $>48$ & 2006 & Bovine/Female & Subclinical mastitis & No & Unknown & Nocardia asteroides type IV \\
\hline 18 & $>48$ & 2006 & Bovine/Female & Clinical mastitis & No & Unknown & Nocardia asteroides type IV \\
\hline 19 & $>48$ & 2006 & Bovine/Female & Clinical mastitis & No & Unknown & Nocardia asteroides type IV \\
\hline 20 & 48 & 2000 & Canine/Female & $\begin{array}{l}\text { Cutaneous- } \\
\text { subcutaneous } \\
\text { abscesses }\end{array}$ & $\begin{array}{c}\text { Canine } \\
\text { distemper }\end{array}$ & Dead & Nocardia otitidiscaviarum \\
\hline 21 & 48 & 2000 & Canine/Female & $\begin{array}{l}\text { Cutaneous- } \\
\text { subcutaneous } \\
\text { abscesses }\end{array}$ & No & Dead & Nocardia otitidiscaviarum \\
\hline 22 & 48 & 2000 & Canine/Female & $\begin{array}{l}\text { Cutaneous- } \\
\text { subcutaneous } \\
\text { abscesses }\end{array}$ & No & Unknown & Nocardia otitidiscaviarum \\
\hline 23 & 24 & 2001 & Canine/Male & $\begin{array}{l}\text { Cutaneous- } \\
\text { subcutaneous } \\
\text { abscesses }\end{array}$ & No & Unknown & Nocardia otitidiscaviarum \\
\hline 24 & $>48$ & 2001 & Canine/Female & Pneumonia & $\begin{array}{c}\text { Canine } \\
\text { distemper }\end{array}$ & Dead & $\begin{array}{l}\text { Nocardia asteroides type III } \\
\text { (N. nova) }\end{array}$ \\
\hline 25 & 06 & 2001 & Canine/Male & $\begin{array}{l}\text { Cutaneous- } \\
\text { subcutaneous } \\
\text { abscesses }\end{array}$ & $\begin{array}{c}\text { Canine } \\
\text { distemper }\end{array}$ & Alive & Nocardia otitidiscaviarum \\
\hline 26 & 03 & 2001 & Canine/Female & $\begin{array}{l}\text { Cutaneous- } \\
\text { subcutaneous } \\
\text { abscesses }\end{array}$ & $\begin{array}{c}\text { Canine } \\
\text { distemper }\end{array}$ & Dead & Nocardia otitidiscaviarum \\
\hline 27 & $>48$ & 2001 & Canine/Male & $\begin{array}{l}\text { Cutaneous- } \\
\text { subcutaneous } \\
\text { abscesses }\end{array}$ & $\begin{array}{c}\text { Canine } \\
\text { distemper }\end{array}$ & Dead & Nocardia asteroides type IV \\
\hline 28 & 06 & 2001 & Canine/Male & $\begin{array}{l}\text { Cutaneous- } \\
\text { subcutaneous } \\
\text { abscesses }\end{array}$ & No & Unknown & Nocardia otitidiscaviarum \\
\hline
\end{tabular}


Table 2

Antimicrobial susceptibility profiles of 28 Nocardia spp. strains isolated from bovine with mastitis and dogs with cutaneous-subcutaneous lesions and pneumonia in Brazil, 2000-2006

\begin{tabular}{lccc}
\hline Antimicrobials & Susceptible & Percentage of strains $(n)$ \\
Intermediate & Resistant & $2(7.2)$ \\
Amikacin $(30 \mu \mathrm{g})$ & $26(92.8)$ & $10(35.7)$ & $1(3.6)$ \\
Amoxicillin $/$ clavulanic acid $(20 / 10 \mu \mathrm{g})$ & $17(60.7)$ & $2(7.2)$ & $8(28.4)$ \\
Ampicillin $(10 \mu \mathrm{g})$ & $18(64.4)$ & $1(3.6)$ & $26(92.8)$ \\
Cefoperazone $(75 \mu \mathrm{g})$ & $1(3.6)$ & $1(3.6)$ & $1(3.6)$ \\
Ceftiofur $(30 \mu \mathrm{g})$ & $26(92.8)$ & $2(7.2)$ & $4(14.2)$ \\
Ceftriaxone $(30 \mu \mathrm{g})$ & $22(78.6)$ & $0(-)$ & $27(96.4)$ \\
Cloxacillin $(5 \mu \mathrm{g})$ & $1(3.6)$ & $0(-)$ & $4(14.2)$ \\
Gentamicin $(10 \mu \mathrm{g})$ & $24(85.8)$ & $0(-)$ & $2(7.2)$ \\
Sulphamethoxazole-trimethoprim $(25 \mu \mathrm{g})$ & $26(92.8)$ & & \\
\hline
\end{tabular}

$\%=$ percentage $\mu \mathrm{g}=$ micrograms

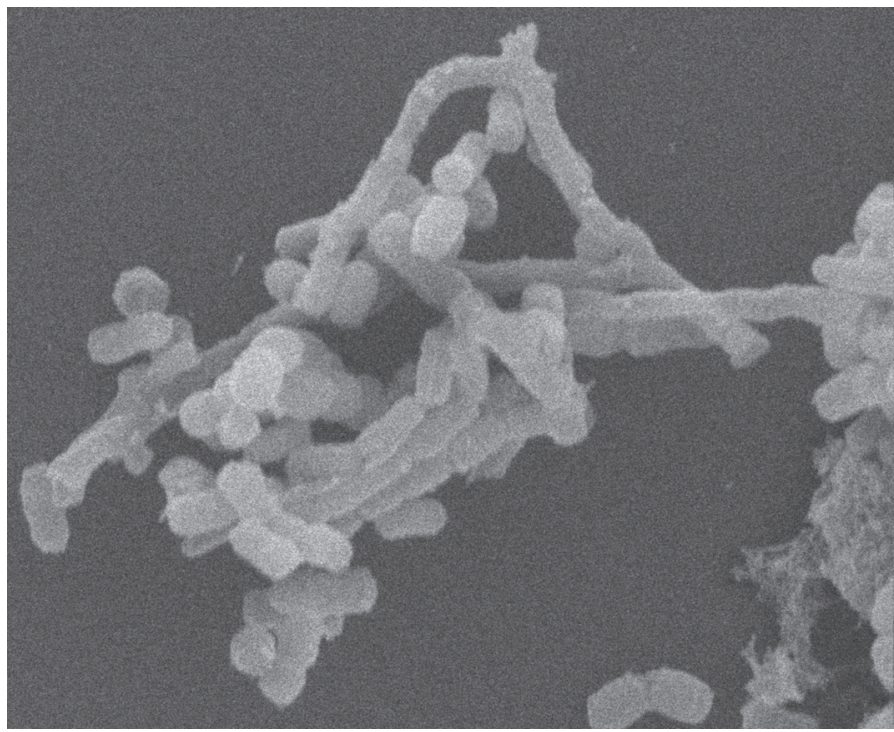

Fig. 3 - Scanning electron micrograph showing detail of coccobacillary to filamentous aspect of Nocardia asteroides type IV strain isolated from bovine mastitis. São Paulo State, Brazil, 2006 (Magnification, 20.000x).

asteroides is recognized as the more important pathogenic specie for human $^{2}$ and animal nocardiosis ${ }^{26,37}$. Nowadays, Nocardia was reclassified in various pathogenic and saprophytic species ${ }^{10,17,40}$. Atypical clinical manifestations of nocardiosis in domestic animals and patients lead frequently to misdiagnose of the disease. In Brazil, has been little consideration to characterize the pathogenic species of Nocardia isolated from different affections in domestic animals.

$N$. asteroides, $N$. brasiliensis, $N$. otitidiscaviarum and $N$. nova are the most common and pathogenic species for companion animals ${ }^{26,45}$. In the present study, $N$. asteroides, $N$. otitidiscaviarum and $N$. nova were also predominantly isolated from the dogs. Data reinforce the virulence and occurrence of these species in canine nocardiosis. Nocardial infections in companion animals are described causing cutaneous-subcutaneous lesions (abscess, mycetoma), with draining sinuses (extrapulmonary nocardiosis), anorexia, pyrexia and weight loss. Complications from cutaneous- subcutaneous nocardial infections in companion animals are associated with invasion of adjacent structures, leading to pulmonary and/or disseminated diseases (peritonitis, encephalitis, osteomyelitis) ${ }^{9,26,49}$. The clinical signs presented in nocardial infections in the nine dogs in this study, is in agreement with findings described previously ${ }^{2,26,27,45}$, including in Brazil ${ }^{39}$, which have also reported nocardiosis predominantly as cutaneous-subcutaneous lesions, and less frequently, pulmonary, neurological or others disseminated forms.

Nocardia spp. are soil saprophytes microorganisms that degrade organic matter, encountered in soil, water and plants ${ }^{6}$. The high frequency of skin lesions in eight dogs studied probably occurred due to inoculation of organism through puncture wounds as previously reported ${ }^{2,27}$, for foreign body, or secondary to bite or scratch after fight of animals by females because the territorial competition ${ }^{39}$.

The nocardiosis in dogs and cats was described in both immunocompetent or immunosuppressed animals. Immunosuppressive infectious diseases in companion animals (distemper in dogs, leukaemia and immunodeficiency in cats) are usually described co-infected with Nocardia $\mathrm{spp}^{26,45}$. Five (55.5\%) from nine dogs reported with cutaneoussubcutaneous or pulmonary nocardiosis in our study had also diagnosis of canine distemper. The immunossuppressive and debilitate organic conditions produced by distemper virus in dogs certainly facilitate the opportunistic comportment of Nocardia strains in establishment of pulmonary and cutaneous-subcutaneous infections, as previously

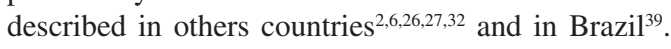

In a survey of 53 dogs presenting nocardiosis, males were three times more frequently infected than females. In the same study, $65.4 \%$, $82.7 \%$ and $7.8 \%$ of the dogs infected were younger than one year, younger than two years and older than six years ${ }^{7}$. In contrast, there was no difference between gender and age on the occurrence of disease in the present study, then nocardiosis occurred both in male and female, and also in young $(<1$ year) and adult animals. Our results may be justified due to frequent combined infection of nocardiosis and canine distemper in Brazil. Canine distemper is an enzootic disease, characterized by a wide age of infection, predisposing the infected animals to opportunistic infectious diseases ${ }^{18,33,34}$, remaining as current health problem in Brazil. 


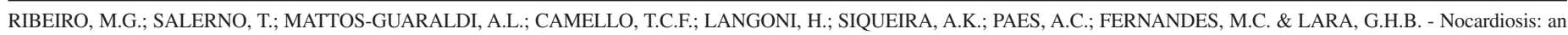
overview and additional report of 28 cases in cattle and dogs. Rev. Inst. Med. trop. S. Paulo, 50(3): 177-185, 2008.

$N$. asteroides, $N$. farcinica, $N$. nova and $N$. otitidiscaviarum were species of microorganism identified in cattle with mastitis in this trial. This result is in agreement with authors who also have described $N$. asteroides, $N$. farcinica and $N$. nova as most common causal agents of nocardial mastitis in domestic ruminants ${ }^{37}$, including in Brazil ${ }^{20,42}$. However, there was no report of bovine mammary infections by $N$. otitidiscaviarum in the literature reviewed. N. otitidiscaviarum usually is described in cats ${ }^{26,31}$ and humans ${ }^{12}$. Thus, bovine mammary infection by $N$. otitidiscaviarum is reported by the first time in Brazil.

Classically, etiological agents of mastitis in domestic ruminants are classified in contagious or environmental microorganisms, related frequently in subclinical and clinical presentations, respectively ${ }^{4,37,42}$. Intramammary infection in domestic ruminants is recognized as the most frequent clinical presentation of nocardiosis, usually affecting one or two cattle in the herd ${ }^{37}$. In the present study, nocardial infections in cows also were identified in one or two animals in dairy herds, predominantly causing clinical mastitis, presenting edema, fibrosis, enlargement to udder, draining sinuses, and milk containing serous to purulent secretion and white particles ("sulfur granules").

Commonly clinical cases of nocardial mastitis are characterized by history of chronic evolution, and refractory to conventional therapy. Mammary infections are associated with inadequate management of milking, especially by soil contamination of udder washing, teat-dip procedure or intramammary infusions in dry period ${ }^{20,37,42}$. Cattle diagnosed with nocardiosis in the present study were also raised in dairy herds with serious hygienic problems in the management of milk, including excess of organic matter in the environment between milking, inadequate concentrations of anti-septic on teat dips, inappropriate hygienic conditions of water used for udder washing and inadequate aseptic procedure for antimicrobial udder infusions, especially in dry cow therapy. Therefore, poor hygiene conditions in milking in dairy herds certainly contribute on the transmission of Nocardia by contamination of water and equipments, or accidental inoculation of organism in udder infusions. The efficacy of therapy in nocardial mastitis is uncertain. The microorganism present intracellular localization, is refractory to conventional antimicrobials, and induce to pyogranulomatous process, extensive fibrosis and glandular damage, that difficult the resolution of mammary inflammatory process ${ }^{6,37}$.

Routine microbiological diagnosis of the genus Nocardia is relatively simple. The organism is Gram-positive, filamentous with tendency to fragmentation, partial acid-fast, isolated in ovine or bovine blood agar and Sabouraud agar, aerobically, after 48 to 72 hours. Microorganisms are usually recovered in pure culture and colonies are smooth or rough, pigmented (white, cream, orange, red tonalities), with characteristic powdery surface, like fungal organisms. However, confirmation of diagnosis and species characterization depend of biochemical characterization, based on hydrolysis of various carbohydrates and other substrates ${ }^{10,28,36}$, and more recently, by use of molecular techniques ${ }^{17,40}$.

Different authors have indicated skin biopsy procedure in diagnosis of companion animals suspect of nocardiosis ${ }^{26,27,45}$, including in Brazil $^{39}$. The aspiration material from cutaneous-subcutaneous lesions in eight dogs allow either cytological identification of Nocardia using different staining methods (Gram, Giemsa), simultaneously to the microbiological culture of organism. Fine needle aspiration of dogs with cutaneous-subcutaneous lesions is characterized by technique of simple execution, low costs, reduced tecidual damage, and enable fast and accurate previous diagnosis of cutaneous-subcutaneous nocardial infection.

In companion animals, differential diagnosis is recommended for Actinomyces species because the microbiological appearance and clinical similarities of this agent with Nocardia spp. ${ }^{26,27,45}$. However, Actinomyces spp. is characterized by facultative anaerobic, non-acidfast, frequently encountered in dense mats of long filamentous organisms in microbiologic and cytologic exams ${ }^{29,36}$. Thus, the presence of Gram-positive, aerobic, partial acid-fast, long filamentous organisms with tendency to fragmentation in cocobacillary forms, identified in cutaneous-subcutaneous or disseminated infections in companion animals is suggestive of nocardiosis ${ }^{26,27,39}$. In contrast, Actinomyces spp. do not represent a problem as a causal agent of mastitis in domestic ruminants ${ }^{37}$. Scanning electron microscopy enabled to observe details of filamentous organisms with tendency to fragmentation, characteristic from the genus Nocardia, in strain isolated from bovine mastitis (Fig. 2 ), confirming the diagnosis of nocardiosis. However, this method rarely has been used on routine diagnosis of animal nocardiosis ${ }^{6}$, due to represent expensive technique and/or by difficulties in accesses to laboratories that development routine of electron microscopy.

Usually nocardial therapy involves prolonged use of antimicrobials combined with surgical debridation/drainage, extirpation of foreign bodies and lavage of infected lesions using anti-septic solutions ${ }^{2,10,19,25,26,30}$. Long-term antimicrobial therapy is recommended due to intracellular localization of agent, development of pyogranulomatous inflammatory reaction and resistant pattern strains that lead to poor response to the conventional antimicrobial treatment ${ }^{10,19,32}$. In companion animals, surgical care procedures are specially indicated in cutaneous-subcutaneous, peritonitis and osteomyelitis manifestations $s^{9,27,45,49}$. Prognosis is uncertain, considered usually good in localized lesions (cutaneous-subcutaneous), but poor to guard in disseminated (systemic), pulmonary and neurological involvement in dogs and cats ct $^{2,26,32,45,49}$ and mastitis in domestic ruminants ${ }^{37,42}$.

Trimethoprim-sulfonamides combinations, aminoglycosides (amikacin), linezolid and late generation beta-lactam compounds (cefotaxime, ceftriaxone, imipenem) used isolated or combined are drugs of choice for nocardial therapy in humans ${ }^{1,10}$ and domestic animals ${ }^{26,45}$. The duration of therapy is uncertain in virtue of relapses after use of shorter course protocols. In companion animals, the therapy in cutaneous lesions is recommended generally from one to three months $s^{2,26,27}$, while in pulmonary, neurological or other systemic infections in animals and human (especially immunocompromised patients), for six to 12 months $^{3,26}$. Additionally, prolonged use of certain antimicrobials (sulfonamides, aminoglycosides) may induce adverse or toxic reactions in nocardial therapy ${ }^{26,32}$.

Efficacy of antimicrobial therapy in companion animals is controversial. Successful management of nocardial empyema in a dog and cat was reported ${ }^{11}$. In contrast, unsuccessful therapy of seven dogs with nocardiosis was described in USA ${ }^{2}$. Likewise, poor success on therapy of nine from ten dogs with nocardiosis, using trimethoprim- 
sulfonamides or cephalosporins was reported in Brazil ${ }^{39}$. In despite of aggressive fluid therapy, surgical drainage and antimicrobial treatment based on in vitro antimicrobial susceptibility tests, five from nine dogs studied dead reinforced the uncertain prognosis and the difficulties on establishment of therapy in canine nocardiosis.

Nocardia spp. organisms show large variation in susceptibility in vitro to different antimicrobials. Sulfonamides-trimethoprim, amikacin and cephalosporins commonly show efficacy in human ${ }^{3,25}$ and animal strains $^{26,45}$. Antimicrobial susceptibility tested in 28 Nocardia strains in this trial showed that amikacin, ceftiophur, sulphamethoxazoletrimethoprim and gentamicin were the most-effective drugs. These results are in agreement with other authors that have indicated sulfonamides combined with trimethoprim, aminoglycosides and cephalosporins as drugs of choice in nocardial therapy in domestic animals $2,26,27,32,37,39,45$. However, these results should be interpreted with care because in vitro susceptibility do not predict necessarily in vivo success in nocardial therapy ${ }^{25,39}$.

Multiple drug resistance in Nocardia strains was observed mainly for cloxacillin, cefoperazone and ampicillin. Interestingly, these drugs from beta-lactam group and derivates that displayed poor efficacy in the Nocardia strains, represent the principal antimicrobials commercialized for bovine intramammary therapy in lactation and dry period in Brazil ${ }^{4}$. Thus, the limitation of use of these antimicrobials difficult the establishment of intramammary therapy procedures for nocardial mastitis in domestic ruminants, reinforcing the elimination of quarters or animals infected by Nocardia as control measure of mammary infections in dairy herds.

Since last taxonomic changes, few studies were conducted in investigation of in vitro susceptibility profile and multiple drug resistance of pathogenic Nocardia strains isolated from domestic animals. Nocardia spp. strains resistant to beta-lactam group and derivates, fluoroquinolones, macrolides and aminoglycosides have been reported ${ }^{25,26}$. The 28 Nocardia strains isolated from cattle and dogs in this trial show multiple drug resistance especially using beta-lactam group and derivates. These results confirm the importance to perform susceptibility antimicrobial tests before initiate nocardial therapy, to increase the efficacy of treatment ${ }^{39}$. Therefore, success on therapy of nocardiosis depends on several factors including virulence of strain, precocious diagnosis, severity and localization of the infection, host immune status, efficacy and potential interactions of antimicrobials used in therapy $y^{3,26}$.

Human nocardiosis is recognized as an opportunistic disease that may occur in either immunocompetent or immunocompromised peoples ${ }^{1}$. In the United States, human nocardiosis was recognized at least in 1,000 cases each year ${ }^{6}$. Clinical cases are intimately related to concurrent immunosuppressive diseases, especially patients committed by aids, organ transplantation, malignancy illness (lymphoma, lymphosarcoma), cirrhosis, diabetes, alcoholism, or prolonged use of corticosteroids ${ }^{1,3,6,19}$. However, 384 from 1,000 cases of nocardiosis described since 1950 , occurred in patients without combined illness or identifiable predisposing factors, representing therefore, primary infections in health human ${ }^{6}$. Clinically, human nocardiosis is manifested often by pulmonary, cutaneous-subcutaneous (mycetoma) and neurological signs ${ }^{1,15,30} . N$. asteroides, $N$. brasiliensis, $N$. farcinica and $N$. nova are species frequently associated to human disease ${ }^{2,19,30,44}$.
The environment is the natural reservoir for both human and animal nocardiosis and suggests that majority transmission of Nocardia spp. for people occur by inhalation of the organism in dry warm climate regions that facilitate the aerosolization and dispersal of pathogen, enhancing the infection by respiratory route. A smaller number of infections are caused by traumatic skin inoculation of organism from soil. Human nocardiosis probably are not thought to be transmitted from person-to-person form, or acquired nosocomially ${ }^{6,44}$. Furthermore, remains unclear the impact of domestic animals as primary reservoir of pathogenic Nocardia spp. strains for human ${ }^{1,6}$. However, several cases of cutaneous-subcutaneous infections transmitted to people by bite or scratch from clinically health dogs and cats have been described ${ }^{1,8,26,41}$. Nocardia spp. are soil saprophytes, opportunistic microorganisms, characterized by infections in several domestic animals. Thus, precautions should be attempted in groups committed by immune dysfunction (patients with aids, organ transplantation, cancer or receiving immunosuppressive drug therapy), with special attention to contact with soil or organic matter contaminated by domestic animals, and management of domestic animals suspected of nocardiosis.

In Brazil, human nocardiosis is recognized as an infrequent disease. Mycetoma and pulmonary infections appears to be predominant clinical manifestations of nocardiosis in this country, followed by neurologic signs $^{10,15,35}$. Severe mycetoma produced by $N$. asteroides was reported in a 9-year-old child that in virtue of severity and evolution of the inflammatory process was submitted to amputation member for resolution of infectious process ${ }^{43}$. Clinical and epidemiological aspects of 41 cases of mycetoma in the city of São Paulo revealed that $68 \%$ were caused by actinomycetes, and from these, $N$. brasiliensis was responsible by 13 cases $^{13}$. Among 71 cases of death in renal transplanted patients, Nocardia sp. was isolated in $10.6 \%{ }^{38}$. Recently, twenty-two cases of nocardial infections diagnosed in Porto Alegre city between 1977-1998 were retrospectively reviewed. This study revealed that six cases were caused by $N$. asteroides complex, one $N$. asteroides sensu strictu, one $N$. brasiliensis and fourteen Nocardia spp., predominantly in immunosuppressed patients (15 cases) and presenting lung infection (17 cases $)^{15}$. Interestingly, in the present study was observed great similarity between Nocardia species (type) isolated from cattle and dogs, and more-common species described by others authors in human nocardiosis $^{1,19,28,30,44}$.

Besides infrequent mammary infections, study attempted to determine the temperature resistance of $N$. asteroides strains isolated from bovine mastitis in Brazil, and revealed that microorganism supported experimental time/temperature conditions usually employed in pasteurization $\left(65{ }^{\circ} \mathrm{C} / 30\right.$ minutes and $75{ }^{\circ} \mathrm{C} / 20$ seconds). All eight strains showed resistance to $65{ }^{\circ} \mathrm{C} / 30$ minutes and seven to $75{ }^{\circ} \mathrm{C} / 20$ seconds, alerting for thermo-tolerance of $N$. asteroides to pasteurization procedures, and potential risk of transmission of microorganism by milk and derivates ${ }^{21}$.

In conclusion, nocardiosis is an unusual opportunistic disease in human and domestic animals, transmitted predominantly from environment. None specific control measures are recommended for nocardiosis in companion animals. However, hygienic environmental conditions, early diagnosis, appropriate initial therapy and control of predisposing factors (immunosuppressive diseases) may decrease the 


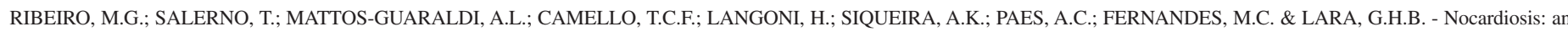
overview and additional report of 28 cases in cattle and dogs. Rev. Inst. Med. trop. S. Paulo, 50(3): 177-185, 2008.

mortality rates in disease. From a similar way, no specific control procedures are indicated to nocardial mastitis. However, properly hygiene conditions at milking, appropriate clean for intramammary infusions, early mastitis diagnosis, chemical drying of affected quarter or elimination of the infected animals, remains as the best methods of the control of nocardial mastitis in domestic ruminants. Due to low prevalence and atypical clinical manifestations, the disease is usually misdiagnosed. The prognosis and efficacy of therapy is uncertain, and antimicrobials are used by long time. Great similarity was observed between Nocardia species identified in the dogs and cattle studied, with isolates described previously in human nocardiosis. Bovine intramammary infections by $N$. otitidiscaviarum are reported by first time in Brazil. Studies of type characterization, virulence, clinicalepidemiological features and predisposing factors from Nocardia strains isolated from human, animal and environmental origin may elucidate risk factors related to nocardial infections.

\section{RESUMO}

\section{Nocardiose: visão geral e relato de 28 casos em vacas e cães}

A caracterização fenotípica, perfil de sensibilidade aos antimicrobianos e aspectos clínico-epidemiológicos foram avaliados em 28 linhagens de Nocardia isoladas de 19 casos de mastite, oito lesões tegumentares e um caso de pneumonia em cão. Foram utilizados no diagnóstico métodos microbiológicos, bioquímicos, citológicos e microscopia eletrônica de varredura. Nocardia asteroides tipo IV, $N$. otitidiscaviarum, $N$. nova (tipo III) e $N$. farcinica (tipo V) foram isoladas do leite de vacas com mastite, de material de lavado transtraqueal e de lesões cutâneas de cães. Nocardiose mamária bovina foi diagnosticada predominantemente sob a forma clínica, em propriedades com precárias condições de higiene na pré e pós-ordenha, e inadequado procedimento de terapia intramamária. Nocardiose canina foi diagnosticada comumente em animais co-infectados com o vírus da cinomose. Sulfametoxazole/trimetoprim $(92,8 \%)$, amicacina $(92,8 \%)$ e ceftiofur $(92,8 \%)$ foram os antimicrobianos mais efetivos frente às linhagens de Nocardia. Resistência múltipla a três ou mais e cinco ou mais antimicrobianos foram observadas, respectivamente, em dez $(35,7 \%)$ e três $(10,7 \%)$ linhagens, notadamente frente à cloxacilina, cefoperazona e ampicilina. A caracterização de espécies (tipo), aspectos clínico-epidemiológicos, diagnóstico, resistência múltipla aos antimicrobianos e reflexos em saúde pública de linhagens de Nocardia isoladas de bovinos e cães no Brasil foram discutidos. Foi destacada a similaridade entre as espécies de Nocardia isoladas de animais e do homem, e a primeira descrição no Brasil de $N$. otitidiscaviarum na etiologia da mastite bovina.

\section{REFERENCES}

1. ACHA, P.N. \& SZYFRES, B. - Nocardiosis. In:__ Zoonosis y enfermedades transmisibles communes al hombre y a los animals. 3. ed. Washington, Organización Panamericana de la Salud, 2003. v.1, p.212-216.

2. ACKERMAN, N.; GRAIN Jr., E. \& CASTLEMAN, W. - Canine nocardiosis. J. Amer. Anim. Hosp. Ass., 18: 147-153, 1982.

3. AGTEROF, M.J.; VAN DER BRUGGEN, T.; TERSMETTE, M. et al. - Nocardiosis: a case series and a mini review of clinical and microbiological features. Neth. J. Med., 65: 199-202, 2007.
4. ANDRADE, S.F.; GIUFFRIDA, R. \& RIBEIRO, M.G. - Quimioterápicos, antimicrobianos e antibióticos. In: ANDRADE, S.F. Manual de terapêutica veterinária. 2. ed. São Paulo, Roca, 2002. p.13-58.

5. BAUER, A.W.; KIRBY, W.M.; SHERRIS, J.C. \& TURCK, M. - Antibiotic susceptibility testing by a standardized single disk method. Amer. J. clin. Path., 45: 493-496, 1966.

6. BEAMAN, B.L. \& BEAMAN, L. - Nocardia species: host-parasite relationships. Clin. Microbiol. Rev., 7: 213-264, 1994.

7. BEAMAN, B.L. \& SUGAR, A.M. - Nocardia in naturally acquired and experimental infections in animals. J. Hyg. (Lond.), 91: 393-419, 1983.

8. BOTTEI, E.; FLAHERTY, J.P.; KAPLAN, L.J. \& DUFFEE-KERR, L. Lymphocutaneous Nocardia brasiliensis infection via cat scratch: a second case. Clin. infect. Dis., 18: 649-650, 1994.

9. BRADNEY, I.W. - Vertebral osteomyelitis due to Nocardia in a dog. Aust. vet. J., 62 : 315-316, 1985.

10. BROWN, J.M. \& McNEIL, M.M. - Nocardia, Rhodococcus, Gordonia, Actinomadura, Streptomyces, and other aerobic actinomycetes In: MURRAY, P.R.; BARON, E.J.; JORGENSEN, J.H.; PFALLER, M.A. \& YOLKEN, R.H. Manual of clinical Microbiology. 8. ed. Washington, ASM Press, 2003. p. 502-531.

11. CAMPBEL, B. \& SCOTT, D.W. - Successful management of nocardial empyema in a dog and cat. J. Amer. Anim. Hosp. Ass., 11: 769-773, 1975.

12. CASTELLI, L.; ZLOTNIK, H.; PONTI, R. \& VIDOTTO, V. - First reported Nocardia otitidiscaviarum infection in an AIDS patient in Italy. Mycopathologia (Den Haag), 126: 131-136, 1994.

13. CASTRO, L.G.; BELDA JÚNIOR, W.; SALEBIAN, A. \& CUCÉ, L.C. - Mycetoma: a retrospective study of 41 cases seen in São Paulo, Brazil, from 1978 to 1989. Mycoses, 36: 89-95, 1993.

14. CASTRO, L.G.M.; VALENTE, N.Y.S.; GERMANO, J.A.M.; VACCARI, E.M. \& da SILVA LACAZ, C. - Mycetoma in an HIV-infected patient. Rev. Hosp. Clín. Fac. Med. S. Paulo, 54: 169-171, 1999.

15. CHEDID, M.B.; CHEDID, M.F.; PORTO, N.S.; SEVERO, C.B. \& SEVERO, L.C. Nocardial infections: report of 22 cases. Rev. Inst. Med. trop. S. Paulo, 49: 239246, 2007.

16. CLINICAL AND LABORATORY STANDARDS INSTITUTE - Performance standards for antimicrobial disk susceptibility test. 8. ed. Pennsylvania, CLSINCCLS, 2003.

17. CONVILLE, P.S. \& WITEBSKY, F.G. - Current issues pertaining to the Nocardia species. Clin. Microbiol. Newsl., 26: 57-62, 2004.

18. CORRÊA, W.M. \& CORRÊA, C.N.M. - Nocardioses. In: __. Enfermidades infecciosas dos mamíferos domésticos. Rio de Janeiro, Medsi, 1992. p. 355-360.

19. CORTI, M.E. \& VILLAFAÑE-FIOTI, M.F. - Nocardiosis: a review. Int. J. infect. Dis., 7: 243-250, 2003.

20. COSTA, E.O.; MACEDO, M.M.; COUTINHO, S.D. et al. - Isolamento de Actinomicetales aeróbios do gênero Nocardia de processos infecciosos dos animais domésticos. Rev. Fac. Med. vet. Univ. S. Paulo, 24: 17-21, 1987.

21. COSTA, E.O.; RIBEIRO, A.R.; RIBEIRO, M.G. et al. - Nocardia sp. strains isolated from clinical and subclinical bovine mastitis: evaluation of the thermic resistance on the milk pasteurization (temperatura/time). In: WORLD BUIATRIC CONGRESS, 19., Edinburgh, 1996. Proceedings. p. 206-207.

22. COSTA, E.O.; RIBEIRO, A.R.; WATANABE, E.T. \& MELVILLE, P.A. - Infectious bovine mastitis caused by environment organisms. Zbl. Veterinarmed. B, 45: 65-71, 1998. 

overview and additional report of 28 cases in cattle and dogs. Rev. Inst. Med. trop. S. Paulo, 50(3): 177-185, 2008.

23. COSTA, E.O.; RIBEIRO, A.R.; WATANABE, E.T. et al. - An increased incidence of mastitis caused by Prototheca species and Nocardia species on a farm in São Paulo, Brazil. Vet. Res. Comun., 20: 237-241, 1996.

24. COSTA, E.O.; RIBEIRO, M.G.; RIBEIRO, A.R. et al. - Diagnosis of clinical bovine mastitis by fine needle aspiration followed by staining and scanning electron microscopy in a Prototheca zopfii outbreak. Mycopathologia, 158: 81-85, 2004.

25. GLUPCZYNSKI, Y.; BERHIN, C.; JANSSENS, M. \& WAUTERS, G. - Determination of antimicrobial susceptibility patterns of Nocardia spp. from clinical specimens by Etest. Clin. Microbiol. Infect., 12: 905-912, 2006.

26. GREENE, C.E. - Actinomycosis and nocardiosis. In:__. Infectious diseases of the dog and cat. 3. ed. Philadelphia, Saunders; Elsevier, 2006. p. 451-461.

27. KIRPENSTEIJN, J. \& FINGLAND, R.B. - Cutaneous actinomycosis and nocardiosis in dogs: 48 cases (1980-1990). J. Amer. vet. med. Ass., 201: 917-920, 1992.

28. KISKA, D.L.; HICKS, K. \& PETTIT, D.J. - Identification of medically relevant Nocardia species with an abbreviated battery of test. J. clin. Microbiol., 40: 1346-1351, 2002.

29. KONEMAN, E.W. - Nocardioforms and aerobic actinomycetes. In: _.Color atlas and textbook of diagnostic microbiology. 4. ed. Philadelphia, Lippincott, 1997. p. 691695.

30. LERNER, P.I. - Nocardiosis. Clin. infect. Dis., 22: 891-905, 1996.

31. LUQUE, R.; ASTORGA, C. \& TARRADAS, B. - Nocardia otitidiscaviarum infection in a cat. Vet. Rec., 151: 488, 2002

32. MARINO, D.J. \& JAGGY, A. - Nocardiosis. A literature review with selected case reports in two dogs. J. Vet. intern. Med., 7: 4-11, 1993.

33. MORETTI, L.D.; DA SILVA, A.V.; RIBEIRO, M.G.; PAES, A.C. \& LANGONI, H. Toxoplasma gondii genotyping in a dog coinfected with distemper virus and ehrlichiosis rickettsia. Rev. Inst. Med. trop. S. Paulo, 48: 359-363, 2006.

34. MORETTI, L.D.; UENO, T.E.; RIBEIRO, M.G. et al. - Toxoplasmose em cães coinfectados com o vírus da cinomose. Semina, 23: 85-92, 2002.

35. PETRILlO, V.F.; SEVERO, L.C.; LONDERO, A.T. \& PORTO, N.S. - Pulmonary nocardiosis report of the first two Brazilian cases. Mycopathologia (Den Haag), 66: $17-20,1978$

36. QUINN, P.J.; CARTER, M.E.; MARKEY, B.K. \& CARTER, G.R. - The Actinomycetes. In:_. Clinical veterinary Microbiology. London, Wolfe, 1994. p. 144-155.

37. RADOSTITS, O.M.; GAY, C.C.; HINCHCLIFF, K.W. \& CONSTABLE, P.D. - Diseases of the mammary gland. In:_. Veterinary Medicine: a textbook of the diseases of cattle, horses, sheep, pigs, and goats. 10. ed. Philadelphia, Saunders; Elsevier, 2007. p. $673-762$.
38. REIS, M.A.; COSTA, R.S. \& FERRAZ, A.S. - Causes of death in renal transplant recipients: a study of 102 autopsies from 1968 to 1991. J. roy. Soc. Med., 88: 24-27, 1995.

39. RIBEIRO, M.G.; AGUIAR, D.M.; PAES, A.C. et al. - Nocardiose cutânea associada à cinomose em cães. Relato de dez casos. Rev. Clín. vet., 39: 34-42, 2002.

40. ROTH, A.; ANDRESS, S.; KROPPENSTEDT, R.M.; HARMSEN, D. \& MAUCH, H. Phylogeny of the genus Nocardia based on reassessed 16S rDNA gene sequences reveals underspeciation and division of strains classified as Nocardia asteroides into three established species and to unnamed taxons. J. clin. Microbiol., 41: 851-856, 2003.

41. SACHS, M.K. - Lymphocutaneous Nocardia brasiliensis infection acquired from a cat scratch: case report and review. Clin. infect. Dis., 15: 710-711, 1992.

42. SANTOS, M.V. \& FONSECA, L.F.L. - Principais agentes causadores de mastite. In: Estratégias para controle de mastite e melhoria da qualidade do leite. São Paulo, Manole, 2007. p.24-37.

43. SARAÇA, G.D.; TOWERSEY, L.; HAY, R.J. et al. - Mycetoma by Nocardia asteroides: a 9 year follow-up. Rev. Inst. Med. trop. S. Paulo, 35: 199-204, 1993.

44. SAUBOLLE, M.A. \& SUSSLAND, D. - Nocardiodis: review of clinical and laboratory experience. J. clin. Microbiol., 41: 4497-4501, 2003.

45. SCOTT, W.; MILLER, W.H. \& GRIFFIN, C.E. - Bacterial skin diseases. In: _. Small Animal Dermatology, 6.ed. Philadelphia, W.B. Saunders, 2001. p.323-324.

46. SCHALM, O.W. \& NOORLANDER, D.O. - Experimental and observation leading to development of California Mastitis Test. J. Amer. Vet. med. Ass., 139: 199-204, 1957.

47. SILVA, A.G., MARTINS, E.M.L.; MARCHIORI, E. et al. - Nocardiose pulmonar em pacientes com síndrome da imunodeficiência adquirida - Relato de caso. Radiol. bras., 35: 1-7, 2000

48. STEINGRUBE, V.A.; BROWN, B.A.; GIBSON, J.L. et al. - DNA amplification and restriction endonuclease analysis for differentiation of 12 species and taxa of Nocardia, including recognition of four new taxa within the Nocardia asteroides complex. J. clin. Microbiol., 33: 3096-3101, 1995

49. TILGNER, S.L. \& ANSTEY, S.I. - Nocardial peritonitis in a cat. Aust. Vet. J., 74: 430 432,1996 .

Received: 26 October 2007

Accepted: 21 February 2008 